TENIDAP, a new anti-inflammatory drug, is presently undergoing clinical studies as a treatment for theumatoid arthritis (RA). Early pilot work has shown it to be of some benefit. Tenidap is a dual inhibitor of cyclo-oxygenase and 5-lipoxygenase enzymes. It has also been shown to modify white blood cell behaviour such as interleukin-1 production, monocyte differentiation and neutrophil degranulation. As free radicals (FRs) have been implicated in the pathogenesis of RA, we used an in vitro assay system developed by Misra and Fridovich to assess if tenidap has FR scavenging effects. Our study shows, for the first time, that tenidap has general FR scavenging effects although no effect on the superoxide anion $\left(\mathrm{O}_{2}^{-}\right)$could be demonstrated. This effect occurred in a dose-dependent manner at concentrations above $20 \mu \mathrm{g} / \mathrm{ml} \quad(p<0.005$, Mann-Whitney U-test). As the therapeutic range of tenidap in serum is between 15 and $30 \mu \mathrm{g} / \mathrm{ml}$ such FR scavenging activity may be clinically relevant in the treatment of RA. $E_{X}$ vivo confirmation of this possibility is underway.

Key words: Free radicals, 5-Lipoxygenase inhibitor, Nonsteroidal anti-inflammatory drug, Rheumatoid arthritis

\section{The in vitro free radical scavenging activity of tenidap, a new dual cyclo-oxygenase and 5-lipoxygenase inhibitor}

\section{S. Lau MB ChB MRCPCA and J. J. F. Belch MD FRCP}

\author{
University Department of Medicine, Ninewells \\ Hospital and Medical School, Dundee DD1 9SY, \\ Scotland, UK \\ ${ }^{\mathrm{CA}}$ Corresponding Author
}

\section{Introduction}

Although the pathophysiology of rheumatoid arthritis (RA) is not fully understood, certain mediators have been shown to be important in the development of inflammation. The role of prostaglandins (PGs), metabolites of arachidonic acid (AA) via the action of cyclo-oxygenase (CO), is well established. ${ }^{1}$ Recently, leukotrienes (LTs), 5lipoxygenase (5-LP) metabolites of AA, have also been shown to be involved in the inflammatory reactions in $\mathrm{RA}^{2}$ Additionally, previous studies have shown reactive oxygen free radicals (FRs) may be important in the development of inflammatory synovitis. ${ }^{3}$

Non-steroidal anti-inflammatory drugs (NSAIs) are widely used in RA and other inflammatory arthropathies. They reduce inflammation via their ability to inhibit CO. ${ }^{1}$ However, most NSAIs at therapeutic levels do not affect LT synthesis. Dual inhibitors of CO and 5-LP might therefore be expected to be superior to $\mathrm{CO}$ inhibitors alone and such agents may offer therapeutic advantages in patients with RA. Tenidap sodium, a novel anti-inflammatory agent, has been shown to have combined CO and 5-LP inhibitory activity ${ }^{4}$ and has been reported to be efficacious in short-term studies of patients with RA. ${ }^{5}$ Another study has shown tenidap to inhibit in vitro activation of human neutrophil collagenase partly due to interference with the production of superoxide radicals
$\left(\mathrm{O}_{2}^{-}\right) .^{6}$ The mechanism of inhibition of $\mathrm{O}_{2}^{--}$production by tenidap is not fully understood although the authors suggested that this may be a secondary phenomenon related to the inhibition of the signal transduction pathway in the neutrophil rather than a direct interaction between tenidap and $\mathrm{O}_{2}^{-}$.

However, if tenidap has antioxidant properties it may be of further therapeutic advantage in patients with RA. For this reason we used an in vitro assay to assess if tenidap was capable of scavenging in vitro production of $\mathrm{O}_{2}^{-}$and other general FRs.

\section{Methods}

The in vitro assay used in this experiment was originally developed by Misra and Fridovich ${ }^{7}$ for the estimation of superoxide dismutase (SOD) activity but it may also be used to differentiate between specific $\mathrm{O}_{2}^{-}$and general FR scavenging activity. This assay is based on the photo-oxidation of o-dianisidine $\left(\mathrm{DH}_{2}\right)$ sensitized by riboflavin $(\mathrm{Rb})$ (Fig. 1). $\mathrm{Rb}$ absorbs a photon and becomes electronically excited $\left(\mathrm{Rb}^{*}\right)$. $\mathrm{Rb}^{*}$ oxidizes $\mathrm{DH}_{2}$ and this leads to the formation of flavin semiquinone $(\mathrm{RbH})$ and the dianisidine radical $\left(\mathrm{DH}^{\circ}\right) . \mathrm{DH}^{\bullet}$ is then involved in further reactions. It may either dismute to yield divalently oxidized dianisidine (D), which absorbs at $460 \mathrm{~nm}$ and is measurable by an ultraviolet/visible spectrophotometer, or be reduced by $\mathrm{O}_{2}^{--}$ion to form $\mathrm{DH}_{2}$ and oxygen $\left(\mathrm{O}_{2}\right)$. The $\mathrm{O}_{2}^{--}$ion involved in the latter reaction is 


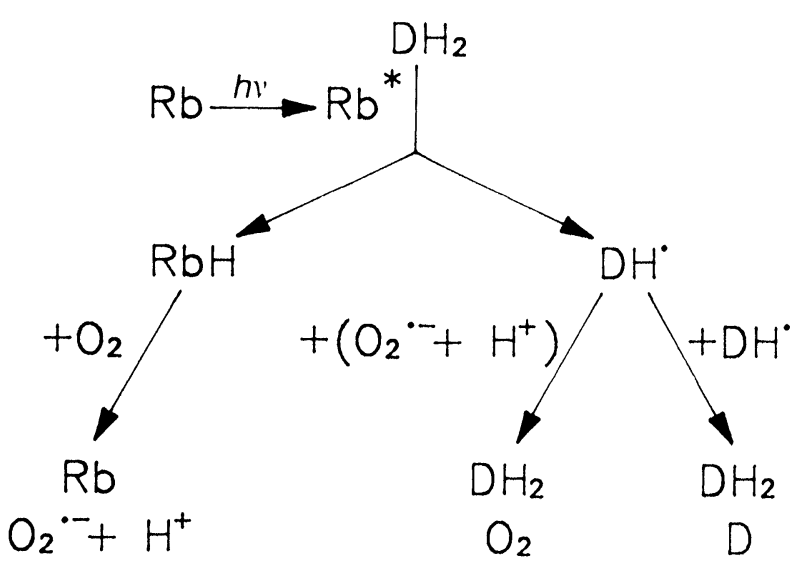

FIG. 1. Photo-oxidation of o-dianisidine. $\mathrm{DH}_{2}$-dianisidine; $\mathrm{DH}-$ dianisidine radical; $\mathrm{D}$-oxidized dianisidine (measurable at $460 \mathrm{~nm}$ ) $\mathrm{Rb}$-riboflavin; $\mathrm{Rb}^{*}$ - excited riboflavin; $\mathrm{RbH}$-flavin semiquinone $h v$-energy of photon of light; $\mathrm{H}^{+}$-hydrogen ion; $\mathrm{O}_{2}$-oxygen $\mathrm{O}_{2}^{-}-$superoxide anion.

supplied by the reduction of $\mathrm{O}_{2}$ by $\mathrm{RbH}$. Thus, an agent with $\mathrm{O}_{2}^{--}$scavenging activity will divert $\mathrm{DH}^{\bullet}$ to the oxidative reaction with enhanced formation of $\mathrm{D}$, thereby increasing the absorbance at $460 \mathrm{~nm}$. On the other hand, a general radical scavenging agent will remove $\mathrm{DH}^{\bullet}$, which reduces the formation of $\mathrm{D}$, thereby decreasing the absorbance at $460 \mathrm{~nm}$.

Materials: Tenidap sodium (CP-66,248) (Fig. 2) was obtained from Pfizer Central Research (Sandwich UK). Riboflavin and o-dianisidine were purchased from Sigma Chemicals Ltd. Riboflavin solution $\left(1.3 \times 10^{-5} \mathrm{M}\right)$ was prepared in $0.01 \mathrm{M}$ potassium phosphate buffer, $\mathrm{pH} 7.5$, and o-dianisidine solution $\left(10^{-2} \mathrm{M}\right)$ was prepared in ethanol. Tenidap was dissolved in $0.01 \mathrm{M}$ potassium phosphate buffer solution.

Illumination for the photochemical reaction was provided by a pair of parallel 10 watt white fluorescent tubes mounted $15 \mathrm{~cm}$ apart in an open-ended box lined with aluminium foil. These tubes provided a constant source of wide-band radiation.

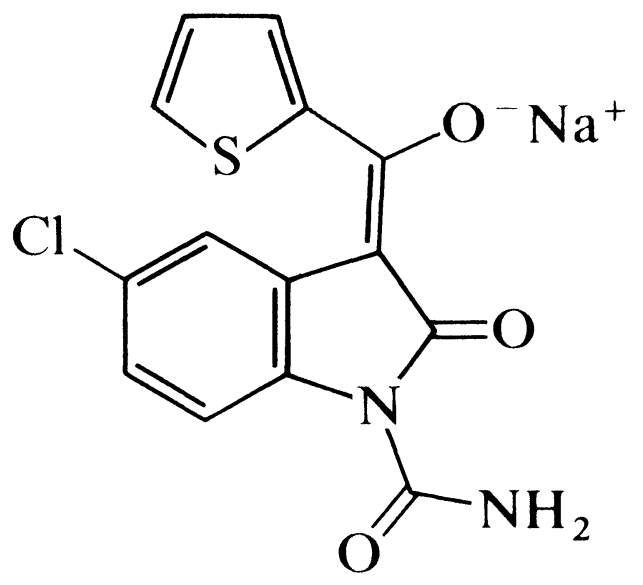

FIG. 2. The molecular structure of tenidap [5-chloro-2,3-dihydro-2-oxo-3(2-thienylcarbonyl)-indole-1-carboxamide].
Assay procedure:

Control sample. Sixty $\mu \mathrm{l}$ of $\mathrm{DH}_{2}$ was added to a cuvette containing $2.94 \mathrm{ml}$ of $\mathrm{Rb}$ solution. Absorbance of light was measured at $460 \mathrm{~nm}$ using a Philips PU 8680 VIS/NIR kinetics spectrophotometer. The cuvette was then placed inside the illumination box for 4 min after which absorbance was measured again at $460 \mathrm{~nm}$. The change in absorbance of this solution was used as the control and was referred to as zero per cent inhibition on the assay.

Tenidap sample. Sixty $\mu \mathrm{l}$ of tenidap solution was added to $2.88 \mathrm{ml}$ of $\mathrm{Rb}$ solution followed by $60 \mu \mathrm{l}$ of $\mathrm{DH}_{2}$ solution and the measurements were carried out as above. Each measurement was repeated on six occasions and percentage inhibition on the assay was calculated at each occasion. Final concentrations of tenidap at $5,10,15,20,22.5,25,30,35$, 40,50 and $60 \mu \mathrm{g} / \mathrm{ml}$ were used.

Statistical analysis: The Mann-Whitney U-test was used to analyse differences between data obtained from the control sample and those from the tenidap samples. A $p$-value of $<0.05$ was considered statistically significant.

\section{Results}

Figure 3 shows the mean (SEM) percentage inhibition on the assay by increasing doses of tenidap. Absorption at $460 \mathrm{~nm}$ was decreased significantly when the final concentrations of tenidap were above $20 \mu \mathrm{g} / \mathrm{ml}$. The higher the concentration of tenidap, the greater the inhibition (all $p<0.005)$.

\section{Discussion}

This study shows, for the first time, that tenidap is a general radical scavenger. We show that it has no effect on $\mathrm{O}_{2}^{-}$but it has general radical

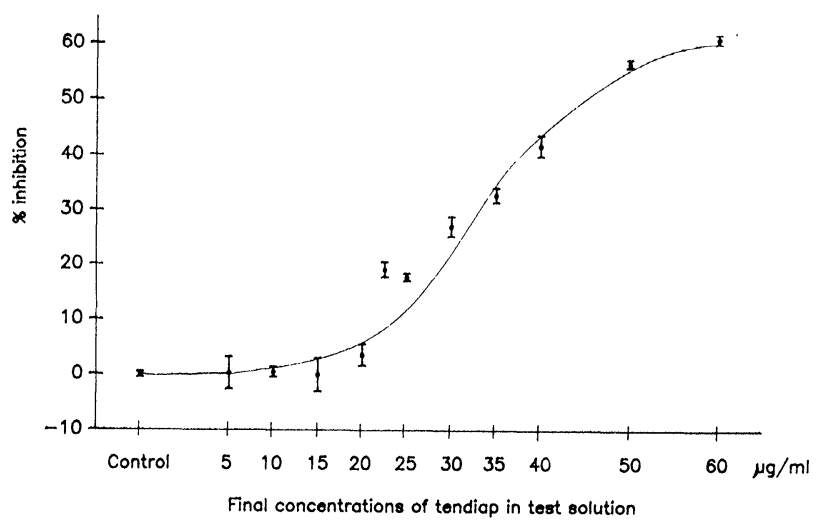

FIG. 3. Percentage inhibition on the assay by tenidap. Results are expressed as mean (SEM). 
scavenging effects which are dose-related at final concentrations above $20 \mu \mathrm{g} / \mathrm{ml}$. This may explain its apparent usefulness in RA, as the therapeutic range of tenidap sodium concentrations in serum is between 15 and $30 \mu \mathrm{g} / \mathrm{ml}$ (Pfizer Central Research).

The use of the in vitro assay of Misra and Fridovich to assess FR scavenging properties of other therapeutic agents has been validated previously. For example, the FR scavenging effects of captopril, an angiotensin converting enzyme inhibitor, and gliclazide, a sulphonylurea hypoglycaemic agent, have been confirmed using this assay. ${ }^{8,9}$ However, this assay system does not demonstrate which part of the test molecule is responsible for its FR scavenging effect. FRs are chemical species (molecule or atom) with an unpaired electron which renders them reactive. In order to achieve a more stable state, FRs try to accept or donate electrons to other compounds. Both captopril, which possesses a sulphydryl group, and gliclazide, with an azabicyclo-octyl ring, are capable of accepting an electron and undergoing conformational changes, thus stabilizing the reactive FRs. It is possible that the carbonyl or carboxamide structure on the tenidap molecule has similar reducing properties and inhibits the production of $\mathrm{DH}^{\cdot}$ by accepting an electron from the excited riboflavin. However, further in vitro studies are required to confirm this hypothesis.

Free radicals are thought to play an important role, both directly and indirectly, in the inflammatory process. ${ }^{10}$ There is now much evidence supporting a pathological role of oxygen FRs in RA. For example, cells that are present in the inflamed joint, such as macrophages, neutrophils, lymphocytes and endothelial cells are all capable of producing FRs when isolated. FRs have been shown in in vitro and animal studies to cause damage to cartilage cells and inhibit a proteoglycan synthesis. ${ }^{3}$ In patients with RA, products of oxidative damage are found in serum and synovial fluid and have been shown to correlate with disease activity. ${ }^{11}$

In conclusion, tenidap is a new anti-inflammatory drug which, unlike other ordinary NSAIs, has additional chemical properties including the inhibition of $5-\mathrm{LP}^{4}$ and neutrophil release reactions. ${ }^{5,6}$ Other authors have also shown it to inhibit the synthesis of interleukin- $1 .{ }^{12}$ Our study suggests that tenidap has further therapeutic properties with an ability to scavenge FRs which may be of relevance in preventing tissue injury in RA. Such activity is particularly interesting as previous in vitro studies have shown 5-LP products, in particular $\mathrm{LTB}_{4}$, to be reactive towards FRs, and it has been suggested that such reactivity may partly explain the chemotactic activity exhibited by LTs. ${ }^{13}$ An $e x$ vivo study of the effects of tenidap on FR activity in patients with RA is currently underway in a double-blind study. The correlation between tenidap's effects on RA activity, and the production and removal of FRs will be assessed. It is hoped that results from this study will improve our understanding of the pathophysiological role of free radicals in rheumatoid arthritis.

\section{References}

1. Higgs GA, Moncada S, Vane JR. Eicosanoids in Inflammation. Ann Clin Res 1984; 16: 287-299.

2. Belch JJF. Eicosanoids and Rheumatology: Inflammatory and vascular aspects. Prostaglandins, Leukotrienes and Essential Fatty Acids 1989; 36: 219 234.

3. Merry P, Winyard PG, Morris CJ, Grootveld M, Blake DR. Oxygen Free Radical, Inflammation, and Synovitis: The current status. Ann Rheum Dis 1989; 48: 864-870.

4. Moilanen E, Alanko J, Asmawi MZ, Vapaatalo H. CP-66,248, a New Anti-inflammatory Agent, is a Potent Inhibitor of Leukotriene $\mathrm{B}_{4}$ and Prostanoid Synthesis in Human Polymorphonuclear Leucocytes in vitro. Eicosanoids 1988; 1: 35-39.

5. Smith DM, Johnson JA, Loeser R, Turner RA. Evaluation of Tenidap (CP-66,248) on Human Neutrophil Arachidonic Acid Metabolism, Chemotactic Potential and Clinical Efficacy in the Treatment of Rheumatoid Arthritis. Agents \&o Actions 1990; 31: 102-109.

6. Blackburn WD, Loose DL, Heck LW, Chatham WW. Tenidap, in Contrast to Several Available Nonsteroidal Antiinflammatory Drugs, Potently Inhibits the Release of Activated Neutrophil Collagenase. Arthritis Rheum 1991; 34(2): 211-216.

7. Misra HP, Fridovich I. Superoxide Dismutase: A photochemical augmentation assay. Arch Biochem Biophys 1977; 187: 303-307.

8. Chopra M, Scott N, McMurray J, Mclay J, Bridges A, Smith WE, Belch JJF. Captopril: A free radical scavenger. Br J Clin Pharmacol 1989: 27: 396 399.

9. Scott NA, Jennings PE, Brown J, Belch JJF. Gliclazide: A general free radical scavenger. Eur J Pharmacol 1991: 208: 175- 177.

10. Dormandy TL. An Approach to Free Radicals. Lancet 1983; ii: 1010-1013.

11. Rowley DA, Gutteridge JMC, Blake DR, Farr M, Halliwell B. Lipid Peroxidation in Rheumatoid Arthritis: Thiobarbituric acid-reactive material and catalytic iron salt in synovial fluid from rheumatoid patients. Clin $S_{c i}$ 1984; 66: 691-695.

12. MacDonald B, Loose L, Rosenwasser LJ. The Influence of a Novel Arachidonate Inhibitor, CP-66,248, on the Production and Activity of Human Monocyte II-1. Artbritis Rheum 1988; 31(4, Suppl): S17.

13. Chopra M, Belch JJF, Smith WE. A Comparison of the Free Radical Scavenging Activity of Leukotrienes and Prostaglandins. Free Rad Res Comms 1988; 5(2): 95-99.

ACKNOWLEDGEMENTS. We are grateful to Pfizer Central Research (Sandwich UK) for financial support and for tenidap sodium. JB is supported by the Sir John Fisher Foundation.

Received 18 October 1991 ; accepted in revised form 6 February 1992 


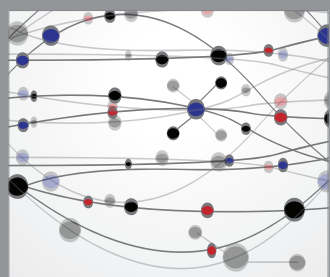

The Scientific World Journal
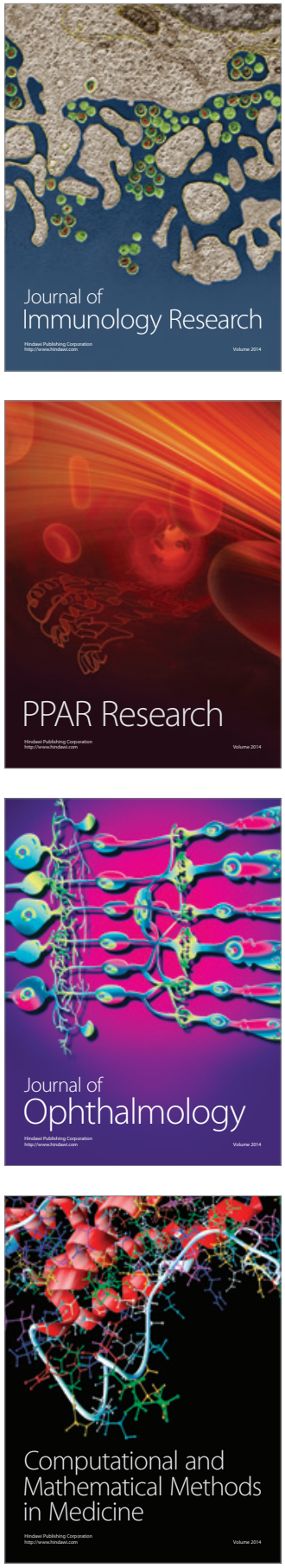

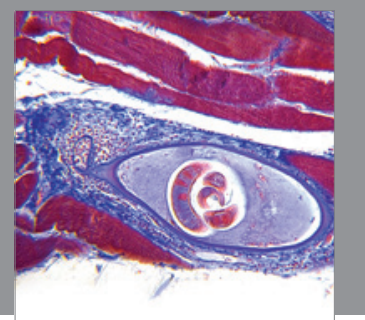

Gastroenterology

Research and Practice
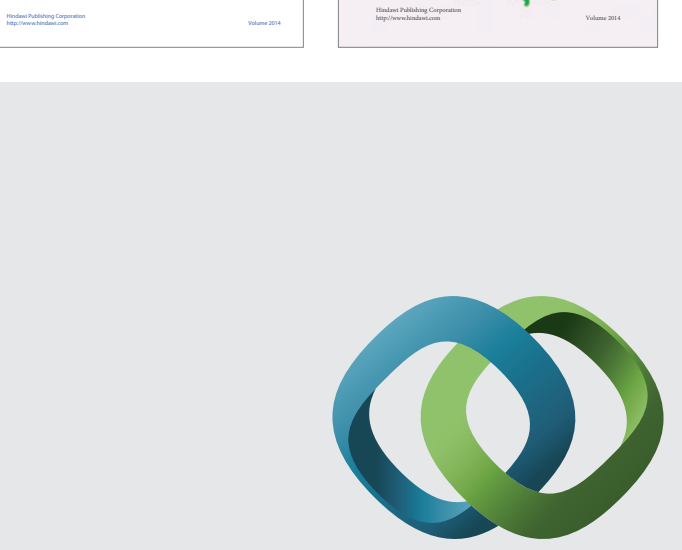

\section{Hindawi}

Submit your manuscripts at

http://www.hindawi.com
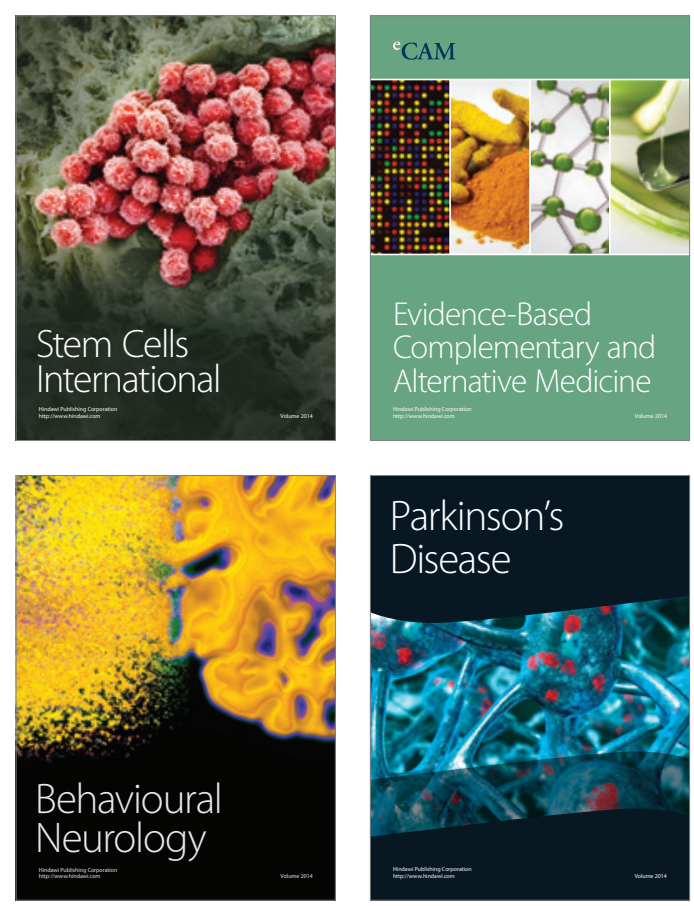

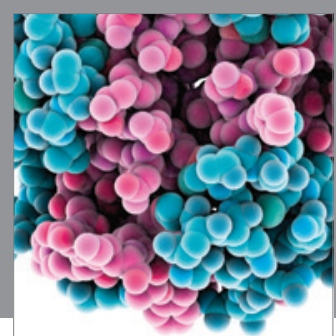

Journal of
Diabetes Research

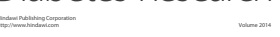

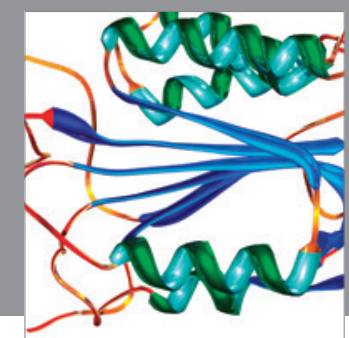

Disease Markers
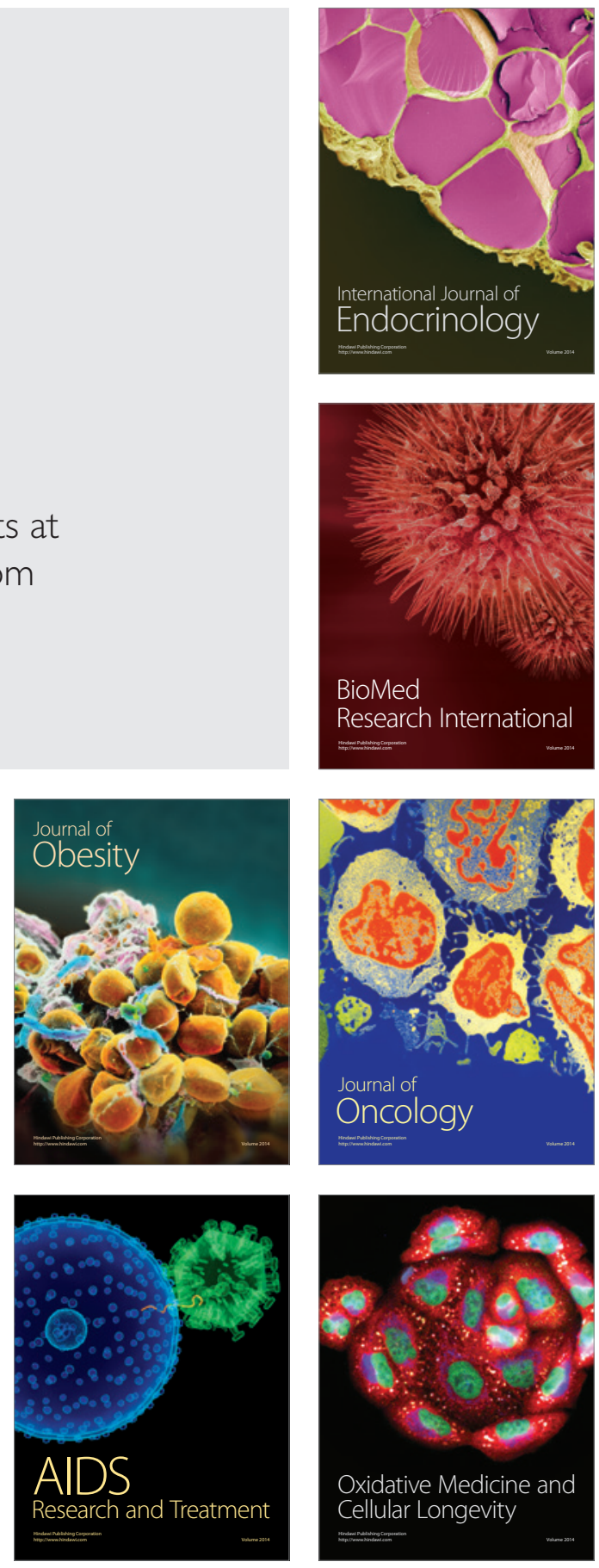